Arch. Tierz., Dummerstorf 51 (2008) 3, 224-234

${ }^{1}$ Research Unit of Reproductive Biology, Research Institute for the Biology of Farm Animals (FBN), Dummerstorf,
Germany
${ }^{2}$ Masterrind, ET-Station Nückel, Germany

HANNELORE ALM ${ }^{1}$, HELMUT TORNER ${ }^{1}$, WILHELM KANITZ ${ }^{1}$, KNUT ROSCHLAU ${ }^{2}$

\title{
Influence of oocyte recovery method, in vitro fertilization method and serum source on embryonic development of in vitro matured bovine oocytes
}

\begin{abstract}
The objective of this study was to investigate the influence of various factors on blastocyst development in a bovine in vitro embryo production system. Two production systems were originally compared: Protocol 1 , which utilized oocyte recovery by slicing, $20 \%$ fetal bovine serum with FSH (FBS+) for oocyte maturation, and sperm preparation system 1 (F1), and Protocol 2, which utilized oocyte recovery by aspiration, $5 \%$ estrous cow serum with FSH, HCG and estradiol (ECS+) for oocyte maturation, and sperm preparation system 2 (F2). Because a significantly higher blastocyst development rate was found for Protocol 2, the different factors of oocyte recovery technique (slicing vs. aspiration), sperm preparation technique (F1 vs. F2) and serum and hormone supplementation during maturation (FBS+ vs. ECS+) were evaluated. Recovering oocytes using the alternative technique (slicing vs. aspiration) did not significantly alter blastocyst rate on Day 8 within either production system 1 (FBS+/F1) or production system $2(\mathrm{ECS}+/ \mathrm{F} 2)$. Although investigations of influence of the type of fertilization method revealed no effect, a significant effect of the type of serum was observed on the blastocyst rates with ECS+ proving better as compared to the use of FBS $+(\mathrm{P}<0.03)$. When embryos produced from these investigations were evaluated by differential staining, the number of ICM cells did not differ among treatment, but the number of TE cells, and thus the total cell number, and the ICM : TCN ratio, was significantly increased when oocytes were matured in ECS+ supplemented medium, regardless of sperm preparation method. In conclusion, serum supplementation, but not oocyte recovery method or sperm preparation method, was responsible for the difference in blastocyst rate between the two original IVP protocols.
\end{abstract}

Keywords: IVP embryos, serum supplementation, blastocyst rate

\section{Zusammenfassung}

Titel der Arbeit: Einfluss der Methode der Oozytengewinnung, der In-vitro-Fertilisation und der Serumquelle auf die embryonale Entwicklung von in-vitro-gereiften Rinderoozyten

Das Ziel der vorliegenden Untersuchungen war es, den Einfluss verschiedener Faktoren auf die Blastozystenentwicklung in einem IVP-System zu untersuchen. Zwei IVP-Systeme wurden verglichen: Protokoll 1 - Oozytengewinnung durch die Schneidetechnik, In-vitro-Maturation mit $20 \%$ FBS und FSH (FBS+), Spermienpräparation (F1); Protokoll 2 - Oozytengewinnung durch Aspiration, In-vitro-Maturation mit $5 \%$ ECS und FSH, HCG, Östradiol-17ß (ECS+), Spermienpräparation (F2). Da im Protokoll 2 eine signifikant höhere Blastozystenrate erzielt wurde, wurden die Gewinnungstechnik (Slicing vs. Aspiration), die Spermienaufbereitung (F1 vs. F2) und die Serum und Hormonsupplementierung (FBS+ vs. ECS+) untersucht. Die Gewinnungsmethode der Oozyten hatte keinen Einfluss auf die Blastozystenentwicklung ebenso wenig wie die Methode der Spermienaufbereitung. Signifikante Unterschiede in der Blastozystenrate am Tag 8 konnten jedoch durch die Verwendung von ECS+ erzielt werden. Nach Anfärbung der Blastozysten war das Verhältnis von ICM : TCM nach Verwendung von ECS+ signifikant erhöht. Zusammenfassend kann festgestellt werden, dass in den vorliegenden Untersuchungen die Blastozystenrate durch die Serumsupplementierung während der IVM und nicht durch die Gewinnungsmethode oder die Spermienaufbereitung erhöht werden konnte.

Schlüsselwörter: In-vitro-Produktion von Embryonen, Serumsupplementierung, Blastozystenrate 


\section{Introduction}

There are many embryo production systems that allow maturation and fertilization of oocytes and development of fertilized zygotes to the morula and blastocyst stages (BAVISTER, 1995; HASLER, 1998).

The culture medium used for oocyte maturation can influence rates of subsequent IVF and embryonic development in cattle (BAVISTER et al., 1992). The in vitro culture media used to produce the embryos are usually supplemented with exogenous protein sources such as serum or bovine serum albumin. Both are complex and non-defined protein source mixtures, possibly contaminated with various small peptides, energy substrates or growth factors (BAVISTER, 1995). Different results in IVM success have been reported with various types of sera or serum protein (YOUNIS et al., 1989; KITO and BAVISTER, 1997), hormones (ZUEHLKE and BRACKETT, 1990; HARPER and BRACKETT, 1993) and growth factors (LONERGAN et al., 1996; SIROTKIN, 1996). In particular, ECS was superior to FBS in the maturation and fertilization rate of bovine oocytes, but the development, which was recorded during $72 \mathrm{~h}$ interval post insemination only, did not differ significantly (YOUNIS et al., 1989).

Protein sources in the IVP media are known to cause changes in the pattern of gene expression of IVP embryos (WRENZYCKI et al., 1999; 2001; RIZOS et al., 2002; 2003). The presence of serum during culture period resulted in a significant increase in the level of gene expression of MnSOD and SOX (oxidative stress), Bax (apoptosis) and LIF (differentiation) and RL- 3 (implantation) (RIZOS et al., 2003).

Defined media in which proteins are replaced by PVA (polyvinyl alcohol) are less able to support embryo development, resulting in embryos that are developmentally compromised. The development to morula, blastocyst and hatched blastocyst stages was higher in medium supplemented with serum than in medium supplemented with PVA (WRENZYCKI et al., 1999; KRISHER et al., 1999), and the heat shock protein mRNA expression was significantly enhanced in serum-generated embryos over embryos cultured in the presence of PVA (WRENZYCKI et al., 1999).

The in vitro production of bovine embryos requires high quality oocytes at the germinal vesicle stage. The ultimate test for the quality of an oocyte is its ability to be fertilized and develop to the blastocyst stage, to establish a pregnancy and to produce a live offspring. From a research standpoint, because of the impracticality of transferring every embryo, attainment of the blastocyst stage is generally used as an indicator of oocyte developmental competence (LONERGAN et al., 2003). The current classification of oocytes is based on the morphology of the cumulus investment around the oocyte (LONERGAN et al., 1994; PAVLOK et al., 1992) and on the appearance of the cytoplasm. The presence of an intact cumulus surrounding the oocyte and the homogeneity of the ooplasm have been the most utilized characteristics of an immature oocyte capable of undergoing maturation and embryonic development (GORDON, 2003).

However, partially denuded oocytes are also able to mature in vitro, although the maturation rate is significantly reduced in comparison to the group with compact cumulus investment (44 vs. $71 \%$ ) (LEIBFRIED and FIRST, 1979).

The cell number of the total embryo and of the ICM appear to be dependent on the culture medium used (VAN SOOM et al., 1996). Therefore, the environment during maturation and early embryonic development clearly plays a role in determining the cell number of the embryo. Since cell number is a valid indicator of embryo quality 
(LONERGAN et al., 1999; WATSON et al., 2000; FISCHER RUSSEL et al., 2006), differential cell staining of blastocysts is an important technique for embryo biotechnology, e.g. for evaluating the adequacy of culture conditions.

The current study was designed to compare the efficiency of 2 IVP-protocols under variable methods for oocyte recovery, in vitro fertilization and serum supplementation, which could be responsible for differences in development of resulting embryos.

\section{Material and Methods}

All chemicals, if not described separately, were obtained from Sigma-Aldrich, Taufkirchen, Germany.

Two reproducible IVP systems were compared (ALM et al., 2005; ROSCHLAU et al., 2001) and factors possible influencing development efficiency were analysed. In each experiment, both systems were tested in parallel at the same time and with cumulusoocyte complexes from the same oocyte recovery. Three replicates were performed in all experiments and for each comparison.

\section{Oocyte collection}

Bovine ovaries were obtained from a slaughterhouse and transported to the laboratory in sterile PBS (D 6650) held at 35 to $37^{\circ} \mathrm{C}$ within $2.5 \mathrm{~h}$ after slaughter. Upon reaching the laboratory, the ovaries were washed in fresh Dulbecco's PBS and cumulus-oocyte complexes (COCs) were recovered either by slicing the surface of the ovary or by aspiration using an $18 \mathrm{G}$ needle attached to a syringe. The medium used for recovery was TCM 199 with Earle's salts containing $25 \mathrm{mM}$ Hepes (M 7528) supplemented with $10 \%(\mathrm{v} / \mathrm{v})$ heat-treated FBS (F 7524). Oocyte recovery was finished within $1.5 \mathrm{~h}$ of reaching the laboratory. Oocytes having a complete, compact multilayered cumulus and dark evenly granulated cytoplasm were used in the experiments. Oocytes which had no cumulus or where the cumulus cells were pycnotic were not used in the experiments.

\section{In vitro maturation (IVM)}

After selection, the COCs were washed twice in maturation medium either medium TCM 199 supplemented with FBS+ [20\% (v/v) heat-treated FBS and $10 \mu \mathrm{g} / \mathrm{ml} \mathrm{FSH}$ (Ovagen, icp, New Zealand)], or TCM 199 supplemented with ECS+ (5\% estrous cow serum and $3.5 \mu \mathrm{g} / \mathrm{ml} \mathrm{FSH}, 3.5 \mu \mathrm{g} / \mathrm{ml}$ HCG and $1 \mu \mathrm{g} / \mathrm{ml}$ estradiol $17 \beta)$ and then incubated in the appropriate maturation medium under mineral oil at $38.5^{\circ} \mathrm{C}$ in $5 \%$ $\mathrm{CO}_{2}$ in air for $24 \mathrm{~h}$.

The oestrous serum was prepared from five oestrous cows, heat-inactivated $\left(56^{\circ} \mathrm{C}\right.$, $30 \mathrm{~min}$ ), pooled, filtered with a $0.22 \mu \mathrm{m}$ membrane and frozen in aliquots until used.

\section{In vitro fertilization (IVF)}

After IVM, oocytes were fertilized in vitro using frozen-thawed bovine semen. Sperm from a single IVF-tested bull was used for the entire experiment. Two different sperm preparation methods were used.

Procedure F1: This procedure followed the method of LONERGAN et al. (1994). A motile sample of sperm was obtained by swim-up separation as described previously (ALM et al., 2005). Briefly, approximately $0.25 \mathrm{~mL}$ cryopreserved semen was layered 
under $1 \mathrm{~mL}$ capacitation medium (TALP - Tyrode's albumin lactate pyruvate) in an open tube. After $1 \mathrm{~h}$, the uppermost 0.5 to $0.8 \mathrm{~mL}$ of medium containing motile spermatozoa was removed and washed twice at $500 \mathrm{~g}$ for $10 \mathrm{~min}$ with 2 to $3 \mathrm{~mL}$ of capacitation medium. A 50 to $60 \mu \mathrm{L}$ aliquot of the swim-up separated spermatozoa were then diluted with an equal volume of capacitation medium containing $200 \mu \mathrm{g} / \mathrm{mL}$ heparin (H 3393). After incubation for 15 min, the suspension was further diluted with capacitation medium to reduce the concentration of capacitation inductors and to obtain the desired final concentration of spermatozoa for IVF. In vitro fertilization was carried out in TALP medium supplemented with PHE (penicillamine-hypotaurinepinephrine). Five oocytes were placed in a $45 \mu \mathrm{L}$ droplet of fertilization medium (TALP; LONERGAN et al., 1994) and 5 to $8 \mu \mathrm{L}$ of the final sperm suspension were added to each droplet to give a final concentration of approximately $1.0 \times 10^{6}$ motile sperm $/ \mathrm{mL}$ in the fertilization droplet. Fertilization was carried out for $24 \mathrm{~h}$ at $38.5^{\circ} \mathrm{C}$ under $5 \% \mathrm{CO}_{2}$ in $100 \%$ humidified air.

Procedure F2: This procedure followed the method of ROSCHLAU et al. (2001). The motile sperm sample was obtained by swim-up separation. Approximately $200 \mu \mathrm{L}$ of cryopreserved semen was layered under $1 \mathrm{~mL}$ preincubated TALP medium in a tightly closed tube. After $1 \mathrm{~h}$ the uppermost $0.8 \mathrm{~mL}$ of medium containing motile spermatozoa was removed and washed twice with $1 \mathrm{~mL}$ TALP without and once with heparin (16.8 $\mu \mathrm{g} / \mathrm{mL}$ ) for 10 minutes each. Meanwhile, ten oocytes were transferred into $100 \mu \mathrm{L}$ drops of modified TALP medium containing heparin $(10 \mu \mathrm{g} / \mathrm{mL})$ and PHE, and 10 to $13 \mu \mathrm{L}$ of the final sperm suspension were added to each droplet to give a final concentration of approximately $1.0 \times 10^{6}$ motile sperm $/ \mathrm{mL}$ in the fertilization droplet. Fertilization was carried out for $24 \mathrm{~h}$ at $38.5{ }^{\circ} \mathrm{C}$ under $5 \% \mathrm{CO}_{2}$ in $100 \%$ humidified air.

\section{In vitro culture of embryos}

Eighteen to twenty hours after insemination, the presumptive zygotes were denuded and transferred back to the original maturation dish which had earlier been placed back in the incubator after removal of in vitro matured COCs for IVF. After an other $24 \mathrm{~h}$ the obtained embryos were cultured in SOF medium (Synthetic Oviductal Fluid Minitüb, Germany) supplemented with $10 \%$ oestrous cow serum and covered with mineral oil. Embryo culture was performed at $38.5{ }^{\circ} \mathrm{C}$ in $5 \% \mathrm{CO}_{2}, 5 \% \mathrm{O}_{2}$ and $90 \%$ $\mathrm{N}_{2}$. Embryonic cleavage was evaluated at $48 \mathrm{~h}$ (cleavage rate), and blastocyst formation was determined at $192 \mathrm{~h}$ ( 8 days).

\section{Experiment 1}

Oocytes were subjected to two IVP systems, as previously utilized in our laboratory: Protocol 1, utilized oocyte recovery by slicing, FBS+ for oocyte maturation, and sperm preparation system F1. Protocol 2, utilized oocyte recovery by aspiration, ECS+ for oocyte maturation, and sperm preparation system F2.

\section{Experiment 2}

In vitro embryo production was performed as for Experiment 1 , except that the alternative oocyte collection method was used. Thus the two additional treatments were: Oocyte recovery by aspiration, FBS+ and F1, and oocyte recovery slicing, ECS+ and F2. 


\section{Experiment 3}

In vitro embryo production was performed with oocytes recovered by aspiration. The two sperm treatment methods were used with oocytes matured in the presence of the alternative serum supplementation. Thus the two additional treatments were: ECS+/F1, and $\mathrm{FBS}+/ \mathrm{F} 2$.

\section{Evaluation of embryos after IVF}

A random sample of day- 8 expanded blastocysts from all protocols $(\mathrm{n}=10)$ were selected for differential staining. The total number of blastomeres (nuclei) and the ratio of ICM/TCN (inner cell mass/total cell number) in embryos was determined using the method of differential labelling of ICM and trophectoderm cells (TE) previously described by THOUAS et al. (2001) and modified by VAJTA (personal communication). Briefly, the blastocysts were stained in a Triton X 100 and PI containing PBS solution up to $15 \mathrm{~s}$ (depending on the thickness of zona pellucida). After that the blastocysts were incubated at $37^{\circ} \mathrm{C}$ in a Hoechst $33342(20 \mu \mathrm{g} / \mathrm{ml})$ containing glycerol : PBS mixture $(9: 1)$ for 5 to $10 \mathrm{~min}$. After incubation most of the glycerol solution was removed and the embryos were covered by a cover slide. Embryos were examined under a fluorescence microscope. Inner cell mass (ICM) nuclei appeared blue and trophectoderm (TE) nuclei appeared red or pink.

\section{Statistical analyses}

Data were analysed by the Student-Newman-Keuls test following one-way ANOVA (pair wise) using SigmaStat Statistical Analysis System Version 1.0 (Jandel Scientific, San Rafael, CA). Test results having P-values equal to or less than 0.05 were considered to be significant.

\section{Experiment 1}

\section{Results}

The results of the comparison of two methods of IVP of embryos are shown in Table 1. Protocol 2 had significantly higher cleavage and blastocyst development rates.

Table 1

Comparison of two different IVP methods (mean \pm SE) (Vergleich von zwei unterschiedlichen IVP-Methoden)

\begin{tabular}{lccc}
\hline Methods & No. of oocytes & Cleaved day 2, (n) $\%$ & Blastocysts day $8,(\mathrm{n}) \%$ \\
\hline Protocol 1 & 375 & $(263) 71.3 \pm 4.9^{\mathrm{a}}$ & (47) $17.6 \pm 2.8^{\mathrm{a}}$ \\
Protocol 2 & 648 & $(536) 83.7 \pm 2.3^{\mathrm{b}}$ & (194) $37.0 \pm 2.6^{\mathrm{b}}$ \\
\hline
\end{tabular}

$\stackrel{\mathrm{a}: \mathrm{b}}{\mathrm{P}<0.001}$

\section{Experiment 2}

Use of protocol 2 or alternative protocol 2 (ECS+/F2) still yielded significantly higher cleavage and blastocyst development rates than did protocol 1 or alternative protocol 1 (FBS+/F1), even though the oocyte recovery methods were switched (Table 2). When results from each maturation/fertilization method were compared between the two different oocyte recovery methods, there were no significant differences in blastocyst rates, indicating no effect of oocyte recovery method on blastocyst development rate at day 8 . The use of protocol 2 or alternative protocol 2 led to higher blastocyst rates in comparison to protocol 1 or alternative protocol $1(\mathrm{P}<0.01)$. 
Table 2

Effect of using the alternative recovery method in two different IVP protocols on embryonic development within each maturation/fertilization system (mean $\pm \mathrm{SE}$ ) (Einfluss einer alternativen Gewinnungsmethode in zwei unterschiedlichen IVP-Protokollen auf die embryonale Entwicklung innerhalb eines jeden Reifungs- und Befruchtungssystems)

\begin{tabular}{lcccc}
\hline Methods & Type of recovery & No. of oocytes & Cleaved day 2, (n) \% & Blastocysts day 8, (n) $\%$ \\
\hline Protocol 1 & slicing & 375 & $(263) 71.3 \pm 4.9^{\mathrm{a}}$ & $(47) 17.6 \pm 2.8^{\mathrm{a}}$ \\
Alternative protocol 1 & aspiration & 317 & $(217) 67.7 \pm 3.8^{\mathrm{a}}$ & $(38) 17.0 \pm 2.3^{\mathrm{a}}$ \\
Protocol 2 & aspiration & 327 & $(276) 85.5 \pm 3.5^{\mathrm{b}}$ & $(113) 41.8 \pm 1.6^{\mathrm{b}}$ \\
Alternative protocol 2 & slicing & 405 & $(269) 64.5 \pm 3.0^{\mathrm{a}}$ & $(101) 38.3 \pm 1.1^{\mathrm{b}}$ \\
\hline
\end{tabular}

a:b Within columns, values with different superscripts differ significantly $(\mathrm{P}<0.01)$

\section{Experiment 3}

As we did not obtain differences after using different recovery methods, we used for the next experiments only the aspiration method for oocyte recovery.

Within each serum treatment group no differences in blastocyst rates were found (Table 3) indicating no effect of fertilization method. Only the type of serum influenced significantly the blastocyst rate $(\mathrm{ECS}>$ FBS, $\mathrm{P}<0.03)$.

Table 3

Effect of using the alternative fertilization method and type of serum during in vitro maturation on embryonic development in vitro (mean $\pm \mathrm{SE}$ ). Oocytes were recovered by aspiration (Einfluss einer alternativen Fertilisationsmethode und des Serums während der In-vitro-Reifung auf die embryonale Entwicklung in vitro. Oozytengewinnung durch Aspiration)

\begin{tabular}{lccc}
\hline $\begin{array}{l}\text { Type of serum/ } \\
\text { fertilization method }\end{array}$ & No. of oocytes & Cleaved day 2, (n) $\%$ & Blastocysts day $8,(\mathrm{n}) \%$ \\
\hline FBS/F1 & 317 & $(217) 67.7 \pm 3.8^{\mathrm{a}}$ & $(38) 17.0 \pm 2.3^{\mathrm{a}}$ \\
FBS/F2 & 223 & $(162) 71.2 \pm 9.7$ & $(46) 25.5 \pm 6.5^{\mathrm{a}}$ \\
ECS/F1 & 162 & $(129) 79.4 \pm 1.5$ & $(44) 33.9 \pm 4.7^{\mathrm{b}}$ \\
ECS/F2 & 327 & $(276) 85.5 \pm 3.5^{\mathrm{b}}$ & $(113) 41.8 \pm 1.6^{\mathrm{b}}$ \\
\hline
\end{tabular}

$\mathrm{a}: \mathrm{b}=$ Within columns, values with different superscripts differ significantly $(\mathrm{P}<0.03)$

Embryos in the blastocyst stage had normal morphology in all treatments. The total cell numbers and the number of trophectoderm cells in the blastocysts were significantly increased in embryos after oocyte maturation with ECS+, resulting in a lower ICM:TCN ratio in these embryos. The cell numbers of ICM were comparable among groups (Table 4).

Table 4

Total number of nuclei and proportion of ICM and TCN in in vitro produced bovine blastocysts on day 8 after IVF (Anzahl der Zellkerne und Verhältnis von ICM zu TCN in in-vitro-produzierten Blastozysten am Tag 8 nach IVF)

\begin{tabular}{lcccc}
\hline Group & Total cell number & No. ICM cells & No. TE cells & ICM/TCN ratio* \\
\hline FBS/F1 & $122.2 \pm 5.2^{\mathrm{a}}$ & $37.3 \pm 1.9$ & $85.0 \pm 4.2^{\mathrm{a}}$ & $0.30 \pm 0.04^{\mathrm{a}}$ \\
FBS/F2 & $131.5 \pm 7.6$ & $42.0 \pm 2.1$ & $89.5 \pm 6.8$ & $0.32 \pm 0.05^{\mathrm{a}, \mathrm{c}}$ \\
ECS/F1 & $134.5 \pm 7.5$ & $36.7 \pm 1.5$ & $97.8 \pm 6.1$ & $0.27 \pm 0.02^{\mathrm{d}}$ \\
ECS/F2 & $141.2 \pm 6.1^{\mathrm{b}}$ & $37.0 \pm 1.7$ & $104.2 \pm 4.9^{\mathrm{b}}$ & $0.26 \pm 0.02^{\mathrm{b}}$ \\
\hline
\end{tabular}

a:b, c: $\mathrm{d}^{ }$Superscript letters indicate significant differences $(\mathrm{P}<0.05) ; \mathrm{n}=10$ blastocysts/group; data depicted as means $\pm \mathrm{SE}\left({ }^{*} \mathrm{mean} \pm \mathrm{SD}\right)$.

\section{Discussion}

Successful production of high quality blastocysts in vitro depends on the use of a culture system, including oocyte recovery, that ensures the acquisition of developmental competence by the maturing oocyte. 
The in vitro maturation environment has a major influence on the oocyte ability to acquire the potential to develop to the blastocyst stage. Of the components added to media to improve development, protein (e.g. serum albumin) and serum appear to have the most influence on embryo development, morphology and metabolism (CAROLAN et al., 1995; THOMPSON, 1997).

In the present study we evaluated the impact of two IVP methods which differed in the method of recovery, types and level of serum and hormone supplement (FBS and ECS) and by sperm preparation technique on the yield and quality of embryos developed in vitro. Aspiration and slicing are both commonly used to recover bovine COCs. Our results show no effect of recovery method on blastocyst development within the maturation and sperm preparation systems used. Previous investigations by CAROLAN et al. (1994) in cattle also showed that the recovery method by aspiration or surface dissection did not have a significant effect on cleavage rate or blastocysts yield after IVP procedure. Similar results were obtained in goats, in which no significant differences were seen in the subsequent percentages of oocytes maturing, being fertilized and developing in vitro among the slicing and aspiration methods of recovering oocytes (PAWSHE et al., 1994; MARTINO et al., 1994).

Sperm preparation for IVF was carried out in the present study by swim-up but with two different protocols for sperm washes. The sperm treatment itself did not influence the blastocyst development. In other species, such as goats, different semen preparation techniques did not affect the penetration and cleavage rates of oocytes (PALOMO et al., 1999).

The type of protein supplementation is thought to play an important role in culture media as a source of growth factor(s) promoting embryonic development directly and/or indirectly via cumulus-cell-proliferation. Different types of protein supplementation used in culture media can greatly influence in vitro development of mammalian embryos, ranging from marked stimulation to significant inhibitory effects (BAVISTER, 1995; PINYOPUMMINTR and BAVISTER, 1991). Different protein sources or serum concentrations supplemented to the maturation and culture media affect the kinetics of the embryo development and the developmental rates. The blastocyst formation $(27 \%)$ and hatching rates $(21 \%)$ were significantly higher in IVP bovine embryos produced with $20 \%$ ECS in the maturation medium than the groups with lower serum concentrations or bovine serum albumin (BSA) (DE OLIVIERA et al., 2006). The use of ECS during both IVM and embryo culture led to a blastocyst rate of $33.9 \%$ (KHURANA and NIEMANN, 2000). However, own unpublished data showed that an increase in the amount of ECS from 5 to $20 \%$ had negative effect on the development (cleavage rate $77.3 \%$, blastocysts rate $32.4 \%$ with $5 \%$ ECS vs. 60.7 and $15 \%$ respectively with $20 \%$ ECS). The quality of serum can vary greatly depending upon the source (animal and/or supplier) (PINYOPUMMINTR and BAVISTER, 1994). Variations in the serum supplements make the comparison of results among laboratories and experiments even more difficult.

The cleavage rate in our experiments using ECS+ instead of FBS was significantly increased (86.0 vs. $67.7 \%$ ) and was higher than that in other reports (ECKERT and NIEMANN, 1995; DE OLIVEIRA et al., 2006). Blastocyst formation was significantly higher in embryos resulting from oocytes matured in ECS + . The ECS+ supplementation led not only to higher blastocyst production rates but also to earlier appearance of blastocysts than FBS supplementation (by the use of ECS, $41.3 \%$ of the 
total number of blastocysts could already be recovered on day 7 as compared to only $29.2 \%$ after the use of FBS - results not shown), which is in agreement with other data (PINYOPUMMINTR and BAVISTER, 1994; LONERGAN et al., 1999; DE OLIVEIRA et al., 2006).

The number of cells of the total embryo and of the ICM has often been used to evaluate embryo quality (KNIJN et al., 2003). The total cell number of blastomeres and the allocation of cells to the trophectoderm and inner cell mass layers of the blastocyst have been correlated to the ability of embryos to survive in utero in term (HARDY et al., 1989). The total number of cells in the blastocysts in our experiments was affected by the oocyte maturation supplement. The total cell counts of embryos derived from oocytes matured in ECS+ were higher than that of the FBS+ groups. Similar results were obtained by MUCCI et al. (2006) in maturation medium with $10 \%$ ECS. An influence of protein sources on the total cell number was also observed by FISCHER RUSSELL et al. (2006), who compared different serum concentrations $(2 \%$ and $10 \%)$ and BSA. In that study the total cell number of embryos derived from oocytes matured in TCM 199 with either $10 \%$ or $2 \%$ serum was significantly higher than was those of blastocysts derived from oocytes cultured with BSA.

It has been shown that the number of cell allocation to the ICM is positively correlated to embryonic survival (IWASAKI et al., 1990; KNIJN et al., 2003) and postimplantation development. The total cell number and the number of TE cells in day 8 blastocysts in our experiments were influenced by type of serum supplement during oocyte maturation in vitro. The ratio of ICM/TCN using ESC+ is comparable to results obtained by FISCHER RUSSEL et al. (2006).

The importance of the ICM:TE cell ratio was shown in investigations of nuclear transfer (NT). The results suggest that NT embryos having fewer TE cells in blastocyst stage may form abnormal placentas, eventually leading to fetal loss (KOO et al., 2002). The reduction in the TE:ICM cell ratio may induce the development of smaller interface of embryonic communication with the uterine environment compromising the capacity of these embryos to survive in vivo (FISCHER RUSSEL et al., 2006).

In conclusion the serum supplementation used during oocyte maturation affected the number and the morphological feature of blastocysts produced in vitro including total cell number count and allocation of cells to trophectoderm (TE) and inner cell mass (ICM) lineages. These results show that the type of serum supplementation during oocyte maturation in vitro have a strong impact on the quality of embryos produced in vitro and emphasize the need for more in depth evaluation of oocyte maturation protocols.

Acknowledgments

The authors thank Prof. Dr. Katrin Hinrichs, Texas A\&M University, for the review of the manuscript.

\section{References}

ALM, H.; TORNER, H.; LÖHRKE, B.; VIERGUTZ, T.; GHONEIM, I.M.; KANITZ, W.:

Bovine blastocyst development rate in vitro is influenced by selection of oocytes by brillant cresyl blue staining before IVM as indicator for glucose-6-phosphate dehydrogenase activity. Theriogenology 63 (2005), 2194-2205 
BAVISTER, B.D.:

Culture of preimplantation embryos: facts and artefacts. Hum. Reprod. Update 1 (1995), 91-148

BAVISTER, B.D.; ROSE-HELLEKANT, T.A.; PINYOPUMMINTR, T.:

Development of in vitro matured/in vitro fertilized bovine embryos into morulae and blastocysts in defined culture media. Theriogenology 37 (1992), 127-145

CAROLAN, C.; LONERGAN, P.; VAN LANGENDONCKT, A.; MERMILLOD, P.:

Factors affecting bovine embryo development in synthetic oviduct fluid following oocyte maturation and fertilization in vitro. Theriogenology 43 (1995), 1115-1128

CAROLAN, C.; MONAGHAN, P.; GALLAGHER, M.; GORDON, I.:

Effect of recovery method on yield of bovine oocytes per ovary and their developmental competence after maturation, fertilization and culture in vitro. Theriogenology 41 (1994), 1061-1068

DE OLIVEIRA, A.T.D.; LOPES, R.F.F.; RODRIGUES, J.L.:

Gene expression and developmental competence of bovine embryos produced in vitro with different serum concentrations. Reprod. Dom. Anim. 41 (2006), 129-136

ECKERT, J.; NIEMANN, H.:

In vitro maturation, fertilization and culture to blastocysts of bovine oocytes in protein-free media.

Theriogenology 43 (1995), 1211-1225

FISCHER RUSSELL, D.; BAQIR, S.; BORDIGNON, J.; BETTS, D.H.:

The impact of oocyte maturation media on early embryonic development. Mol. Reprod. Dev. 73 (2006), $1255-1270$

GORDON, I.:

Recovering the bovine oocyte. In "Laboratory Production of Cattle Embryos", $2^{\text {nd }}$ Edition, 2003 (Biotechnology in Agriculture No. 27) CAB International/Cambridge University Press: Cambridge, UK, 79-111

HARDY, K.; HANDYSIDE, A.H.; WINSTON, R.M.L.:

The human blastocyst: Cell number, death and allocation during late implantation development in vitro. Development 107 (1989), 597-604

HARPER, K.M.; BRACKETT, B.G.:

Bovine blastocyst development after in vitro maturation in a defined medium with epidermal growth factor and low concentrations of gonadotropins. Biol. Reprod. 48 (1993), 409-416

HASLER, J.:

The current status of oocyte recovery, in vitro embryo production, and embryo transfer in domestic animals, with an emphasis on the bovine. J. Anim. Sci. 76 (1998), 52-74

IWASAKI, S.; YOSHIBA, N.; USHIJIMA, H.; WATANABE, S.; NAKAHARA, T.:

Morphology and proportion of inner cell mass of bovine blastocysts fertilized in vitro and in vivo. J. Reprod. Fert. 90 (1990), 279-284

KHURANA, N.K.; NIEMANN, H.:

Effect of oocyte quality, oxygen tension, embryo density, cumulus cells and energy substrates on cleavage and morula/blastocyst formation of bovine embryos. Theriogenology 54 (2000), 741-756

KITO, S.; BAVISTER, B.D.:

Gonadotropins, serum, and amino acids alter nuclear maturation, cumulus expansion, and oocyte morphology in hamster cumulus-oocyte complexes in vitro. Biol. Reprod. 56 (1997), 1281-1289

KNIJN, H.M.; GJORRET, J.; VOS, P.L.A.M.; HENDRIKSEN, P.J.M.; VAN DER WEIJDEN, B.C.;

MADDOX-HYTTEL, P.; DIELEMAN, S.J.:

Consequences of in vivo development and subsequent culture on apoptosis, cell number, and blastocyst formation in bovine embryos. Biol. Reprod. 69 (2003), 1371-1378

KOO, D.B.; KANG, Y.K.; CHOI, Y.H.; PARK, J.S.; KIM, H.N.; OH, K.B.; SON, D.S.; PARK, H.; LEE, K.K.; HAN, Y.M.: Aberrant allocation of inner cell mass and trophectoderm cells in bovine nuclear transfer blastocysts. Biol. Reprod. 67 (2002), 487-492

KRISHER, R.L.; LANE, M.; BAVISTER, B.D.:

Developmental competence and metabolism of bovine embryos cultured in semi-defined and defined media. Biol. Reprod. 60 (1999), 1345-1352

LEIBFRIED, L.; FIRST, N.L.:

Characterization of bovine follicular oocytes and their ability to mature in vitro. J. Anim. Sci. 48 (1979), 76-86

LONERGAN, P.; CAROLAN, C.; VAN LANGENDONCKT, A.; DONNAY, I.; KHATIR, H.; MERMILLOD, P.: Role of epidermal growth factor in bovine oocyte maturation and preimplantation embryo development in vitro. Biol. Reprod. 54 (1996), 1420-1429

LONERGAN, P.; KHATIR, H.; PIUMI, F.; RIEGER, D.; HUMBOLT, P.; BOLAND, M.P.:

Effect of time interval from insemination to first cleavage on the developmental characteristics, sex ration and pregnancy rate after transfer of bovine embryos. J. Reprod. Fert. 117 (1999), 159-167 
LONERGAN, P.; MONAGHAN, P.; RIZOS, D.; BOLAND, M.P.; GORDON, I.:

Effect of follicle size on bovine oocyte quality and developmental competence following maturation, fertilization, and culture in vitro. Molec. Reprod. Dev. 37 (1994), 48-53

LONERGAN, P.; O'KEARNEY-FLYNN, M.; BOLAND, M.P.:

Effect of protein supplementation and presence of an antioxidant on the development of bovine zygotes in synthetic oviduct fluid medium under high or low oxygen tension. Theriogenology 51 (1999), 1565-1576

LONERGAN, P.; RIZOS, D.; GUTIERREZ-ADAN, A.; FAIR, T.; BOLAND, M.P.:

Oocyte and embryo quality: effect of origin, culture conditions and gene expression patterns. Reprod. Dom. Anim. 38 (2003), 259-267

MARTINO, A.; PALOMO, M.J.; MOGAS, T.; PARAMIO, M.T.:

Influence of the collection technique pf prepubertal goat oocytes on in vitro maturation and fertilization. Theriogenology 42 (1994), 859-873

MUCCI, N.; ALLER, J.; KAISER, G.G.; HOZBOR, F.; CABODEVILA, J.; ALBERIO, R.H.:

Effect of esrtous cow serum during bovine embryo culture on blastocyst development and cryotolerance after slow freezing or vitrification. Theriogenology 65 (2006), 1551-1562

PALOMO, M.J.; IZQUIERDO, D.; MOGAS, T.; PARAMIO, M.T.:

Effect of sperm preparation on IVF of prepubertal goat oocytes. Theriogenology 51 (1999), 927-940

PAVLOK, A.; LUCAS-HAHN, A.; Niemann, H.:

Fertilization and developmental competence of bovine oocytes from different categories of antral follicles. Molec. Reprod. Dev. 31 (1992), 63-67

PAWSHE, C.H.; TOTEY, S.M.; JAIN, S.K.:

A comparison of three methods of recovery of goat oocytes for in vitro maturation and fertilization. Theriogenology 42 (1994), 117-125

PINYOPUMMINTR, T.; BAVISTER, B.D.:

In vitro matured/in vitro fertilized oocytes can develop into morulae/blastocysts in chemically defined, protein-free culture media. Biol. Reprod. 45 (1991), 736-742

PINYOPUMMINTR, T.; BAVISTER, B.D.:

Development of bovine embryos in a cell free culture medium: effects of type of serum, timing of its inclusion and heat inactivation. Theriogenology 41 (1994), 1241-1249

RIZOS, D.; GUTIÉRREZ-ADÁN, A.; PEREZ-GARNELO, S.; DE LA FUENTE, J.; BOLAND, M.P.; LONERGAN, P.:

Bovine embryo culture in the presence of serum: implications for blastocyst development, cryotolerance, and messenger RNA expression. Biol. Reprod. 68 (2003), 236-243

RIZOS, D.; LONERGAN, P.; BOLAND, M.P.; ARROYO-GARCIA, R.; PINTADO, B.; DE LA FUENTE, J.; GUTIÉRREZ-ADÁN, A.:

Analysis of differential messenger RNA expression between bovine blastocysts produced in different culture systems: implications for blastocyst quality. Biol. Reprod. 66 (2002), 589-595

ROSCHLAU, K.; KUWER, A.; ROSCHLAU, D.; MICHAELIS, U.; DEXNE, U.; KUHNT, C.; POPPE, P.: Practical use of OPU/IVP in modern cattle breeding. Arch. Tierz., Dummerstorf 44 (2001) Special Issue, 99-101

SIROTKIN, A.V.:

Direct action of growth hormone on bovine ovarian cells: effects on estradiol, oxytocin, vasopressin release by granulosa cells and on oocyte maturation and cleavage in vitro. Ann. Endocrinol. 57 (1996), 219-224

THOMPSON, J.G.:

Comparison between in vivo-derived and in vitro-produced pre-elongation embryos from domestic ruminants. Reprod. Fert. Dev. 9 (1997), 341-354

THOUAS, G.A.; KORFIATIS, N.A.; FRENCH, A.J.; JONES, G.M.; TROUNSON, A.O.:

Simplified technique for differential staining of inner cell mass and trophectoderm cells of mouse and bovine blastocysts. RBM Online 3 (2001), 25-29

VAN SOOM, A.; BOERJAN, M.; YSEBAERT, M.T.; DE KRUIF, A.:

Cell allocation to the inner cell mass and the trophectoderm in bovine embryos cultured in two different media. Mol. Reprod. Dev. 45 (1996), 171-182

WATSON, A.J.; DE SOUSA, P.; CAVENEY, A.; BARCROFT, L.C.; NATALE, D.; URQUHART, J.; WESTHUSIN, M.E.:

Impact of bovine oocyte maturation on oocyte transcript level, blastocysts development, cell number, and apoptosis. Biol. Reprod. 62 (2000), 355-364

WRENZYCKI, C.; HERRMANN, D.; CARNWARTH, J.W.; NIEMANN, H.:

Alterations in the relative abundance of gene transcripts in pre-implantation bovine embryos in medium supplemented with either serum or PVA. Mol. Reprod. Dev. 53 (1999), 8-18 
WRENZYCKI, C.; HERRMANN, D.; KESKINTEPE, L.; MARTINS, A.J.R.; SIRISATHIEN, S.; BRACKETT, B.G.; NIEMANN, H.:

Effects of culture system and protein supplementation on mRNA in pre-implantation bovine embryos. Hum. Reprod. 16 (2001), 893-901

YOUNIS, A.I.; BRACKETT, B.G.; FRAYRER-HOSKEN, R.A.:

Influence of serum and hormones on bovine oocyte maturation and fertilization in vitro. Gamete Res. 23 (1989), 189-201

ZUEHLKE, K.A.; BRACKETT, B.G.:

Luteinizing hormone-enhanced in vitro maturation of bovine oocytes with and without protein supplementation. Biol. Reprod. 43 (1990), 784-787

Received: 2008-01-21

Accepted: 2008-04-07

Corresponding author:

Dr. HANNELORE ALM

Research Unit of Reproductive Biology

Research Institute for the Biology of Farm Animals (FBN)

18196 Dummerstorf

Germany

email: alm@fbn-dummerstorf.de 